\title{
A Practical Protocol for the Hiyama Cross-Coupling Reaction Catalyzed by Palladium on Carbon
}

\author{
Yasunari Monguchi, * Takayoshi Yanase, Shigeki Mori, Hironao Sajiki* \\ Laboratory of Organic Chemistry, Gifu Pharmaceutical University, 1-25-4 Daigaku-nishi, \\ Gifu 501-1196, Japan \\ Fax +81(58)2308109; E-mail: monguchi@gifu-pu.ac.jp; E-mail: sajiki@gifu-pu.ac.jp \\ Received: 11.09.2012; Accepted after revision: 20.09.2012
}

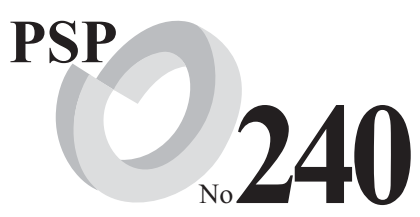

Abstract: A method for the palladium on carbon $(\mathrm{Pd} / \mathrm{C})$ catalyzed cross-coupling reaction between aryl halides and trialkoxy(aryl)silanes in the presence of a small amount of water is established using tris(4-fluorophenyl)phosphine as the ligand. A range of biaryl compounds is prepared using this protocol.

Key words: palladium, cross-coupling, heterogeneous, silicon, biaryls

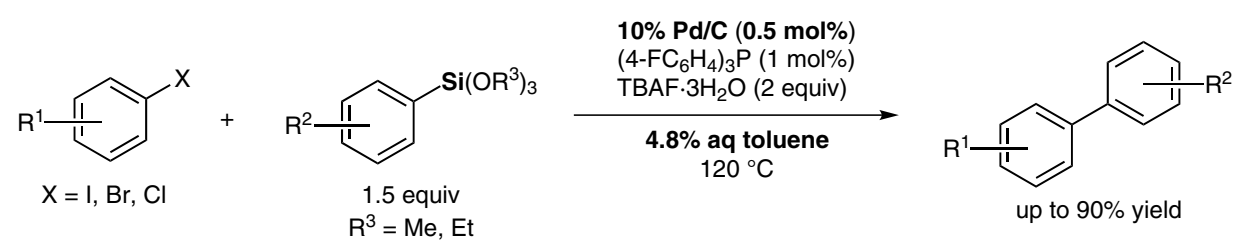

Scheme $1 \mathrm{Pd} / \mathrm{C}$-catalyzed cross-coupling between aryl halides and trialkoxy(aryl)silanes in the presence of $\left(4-\mathrm{F}-\mathrm{C}_{6} \mathrm{H}_{4}\right)_{3} \mathrm{P}, \mathrm{TBAF} \cdot 3 \mathrm{H}_{2} \mathrm{O}$ and a small amount of water in toluene

The palladium-catalyzed cross-coupling reaction between organic halides and organosilanes, the Hiyama coupling, is of practical use due to the low toxicity of organosilanes and the easy access it provides to biaryl skeletons, which are partial structures of various functional molecules, including pharmaceuticals. ${ }^{1,2}$ The development of heterogeneous palladium-catalyzed cross-coupling reactions has attracted significant attention from both environmental and economic points of view, as the catalysts can be readily recovered from the reaction mixture. ${ }^{3}$ Although the application of palladium nanoparticles on surfactants, ${ }^{4}$ polyethylene glycol, ${ }^{5}$ and a dendrimer ${ }^{6}$ have been reported as heterogeneous catalysts for the Hiyama cross-coupling, many of them require complicated procedures for their preparation. We have been interested in the application of palladium on carbon $(\mathrm{Pd} / \mathrm{C})$, a commercially available conventional hydrogenation catalyst, ${ }^{7}$ for crosscoupling reactions..$^{8,9}$ Although a report on the palladium on carbon catalyzed Hiyama coupling was published ${ }^{10}$ during the course of our preparation of a previous communication, ${ }^{11}$ it focused on the variation in the catalyst activity of palladium on carbon supplied by different vendors toward several types of cross-coupling reactions, including the Hiyama reaction. However, the reaction conditions and substrate scope were not investigated in detail. In our above-mentioned communication, the effect of

SYNTHESIS 2013, 45, 0040-0044

Advanced online publication: 09.10.2012

DOI: 10.1055/s-0032-1316801; Art ID: SS-2012-Z0714-PSP

(C) Georg Thieme Verlag Stuttgart · New York water as an additive on the reaction progress, the use of tris(4-fluorophenyl)phosphine $\left[\left(4-\mathrm{FC}_{6} \mathrm{H}_{4}\right)_{3} \mathrm{P}\right]$ as the ligand, and broad substrate applicability were demonstrated. ${ }^{11}$ Furthermore, a ligand-free palladium on carbon catalyzed Hiyama reaction was achieved by the addition of acetic acid. ${ }^{12}$ In this report, a detailed investigation leading to optimized conditions in the presence of tris(4fluorophenyl)phosphine as the ligand, and their applicability to a range of substrates is discussed (Scheme 1).

While the cross-coupling reaction between 1-iodo-4-nitrobenzene and triethoxy(phenyl)silane (1.5 equiv) in the presence of 1,1'-bis(diphenylphosphino)ferrocene (dppf) $(10 \mathrm{~mol} \%)$ and tetra- $n$-butylammonium fluoride trihydrate (TBAF-3 $\left.\mathrm{H}_{2} \mathrm{O}\right)\left(2\right.$ equiv) at $120{ }^{\circ} \mathrm{C}$ (bath temperature) proceeded disappointingly in alcoholic, ethereal, and polar aprotic solvents (Table 1, entries 1-9), toluene was found to be a good solvent leading to the desired crosscoupled product, 4-nitrobiphenyl, in 64\% yield (Table 1, entry 10). Although tetra- $n$-butylammonium fluoride trihydrate and tetra- $n$-butylammonium fluoride in tetrahydrofuran were both able to activate triethoxy(phenyl)silane to promote the cross-coupling (Table 1, entries 10 and 15), no reaction took place using other inorganic fluoride salts, probably due to their poor solubility in toluene (Table 1, entries 11-14). Therefore, tetra- $n$-butylammonium fluoride trihydrate was chosen as the activator of choice for silane derivatives because of its better efficiency in the coupling reactions. 
Table 1 Evaluation of Solvents and Fluoride Sources on the 10\% $\mathrm{Pd} / \mathrm{C}$-Catalyzed Cross-Coupling between 1-Iodo-4-nitrobenzene and Triethoxy(phenyl)silane

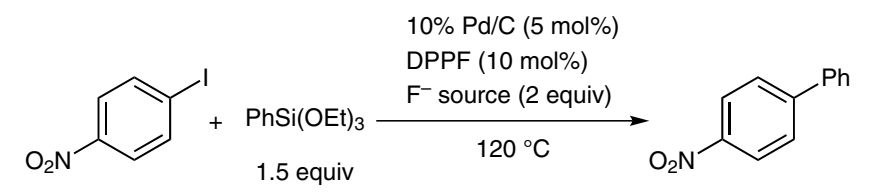

\begin{tabular}{lllll}
\hline Entry & Solvent & $\mathrm{F}^{-}$source & Time (h) & Yield (\%) \\
\hline 1 & $\mathrm{MeOH}$ & $\mathrm{TBAF} \cdot 3 \mathrm{H}_{2} \mathrm{O}$ & 24 & 0 \\
2 & $\mathrm{THF}$ & $\mathrm{TBAF} \cdot 3 \mathrm{H}_{2} \mathrm{O}$ & 8 & 7 \\
3 & $1,4-$ dioxane & $\mathrm{TBAF} \cdot 3 \mathrm{H}_{2} \mathrm{O}$ & 5 & 7 \\
4 & $\mathrm{MeCN}$ & $\mathrm{TBAF} \cdot 3 \mathrm{H}_{2} \mathrm{O}$ & 1 & trace \\
5 & DMPU & $\mathrm{TBAF} \cdot 3 \mathrm{H}_{2} \mathrm{O}$ & 3 & 0 \\
6 & $\mathrm{NMP}$ & $\mathrm{TBAF} \cdot 3 \mathrm{H}_{2} \mathrm{O}$ & 3 & $8^{\mathrm{b}}$ \\
7 & DMF & $\mathrm{TBAF} \cdot 3 \mathrm{H}_{2} \mathrm{O}$ & 1 & 16 \\
8 & DMA & $\mathrm{TBAF} \cdot 3 \mathrm{H}_{2} \mathrm{O}$ & 3 & $17^{\mathrm{b}}$ \\
9 & DMSO & $\mathrm{TBAF} \cdot 3 \mathrm{H}_{2} \mathrm{O}$ & 3 & $24^{\mathrm{b}}$ \\
10 & toluene & $\mathrm{TBAF} \cdot 3 \mathrm{H}_{2} \mathrm{O}$ & 14 & 64 \\
11 & toluene & $\mathrm{NaF}$ & 9 & 0 \\
12 & toluene & $\mathrm{KF}$ & 14 & 0 \\
13 & toluene & $\mathrm{CsF}$ & 14 & 0 \\
14 & toluene & $\mathrm{CuF} 2$ & 9 & 0 \\
15 & toluene & $\mathrm{TBAF}$ in THF & 5 & 52 \\
\hline
\end{tabular}

${ }^{\text {a }}$ Determined by ${ }^{1} \mathrm{H}$ NMR spectroscopy with 1,4-dioxane as the internal standard.

${ }^{\mathrm{b}}$ Yield of isolated product.

${ }^{\mathrm{c}} \mathrm{DMA}=N, N$-dimethylacetamide.

Interestingly, this cross-coupling was found to proceed under ligand-free conditions to afford 4-nitrobiphenyl in $52 \%$ yield (Table 2 , entry 1 ). ${ }^{12}$ No other bidentate ligands, apart from 1,1'-bis(diphenylphosphino)ferrocene, increased the efficiency of the reaction (Table 2, entries 2 5 ). When triphenylphosphine derivatives were employed as monodentate ligands, the reaction efficiency was affected strongly by the electron density of the aromatic nuclei (Table 2, entries 7-14); triphenylphosphine derivatives bearing electron-withdrawing chlorine or fluorine atoms on each aromatic ring were found to be good ligands (Table 2, entries 7 and 8). However, no improvement in the yield was observed when using perfluorinated triphenylphosphine as the ligand (Table 2, entry 9). On the other hand, ligands with one or two electron-donating substituents on the aromatic rings proved to be less effective in this coupling reaction (Table 2, entries 10-14). Furthermore, monodentate phosphine ligands with bulky and non-aromatic substituents on the phosphine atom, such as tricyclohexylphosphine $\left(\mathrm{Cy}_{3} \mathrm{P}\right)$ and 2-(di-tert-bu- tylphosphino)biphenyl (JohnPhos), did not promote the coupling as efficiently (Table 2, entries 15 and 16).

Table 2 Evaluation of Ligands for the 10\% Pd/C-Catalyzed CrossCoupling between 1-Iodo-4-nitrobenzene and Triethoxy(phenyl)silane

\begin{tabular}{|c|c|c|c|c|}
\hline $\mathrm{O}_{2} \mathrm{~N}^{\prime}$ & $\begin{array}{c}+\mathrm{PhSi}(\mathrm{OEt})_{3}- \\
1.5 \text { equiv }\end{array}$ & $\begin{array}{l}0 \% \mathrm{Pd} / \mathrm{C}( \\
\text { igand } \\
\text { rBAF.3 } \mathrm{H}_{2} \mathrm{O} \\
\text { tolue } \\
120\end{array}$ & $\stackrel{\mathrm{O}_{2} \mathrm{~N}}{\stackrel{\mathrm{mol} \%)}{2 \text { equiv) }}}$ & 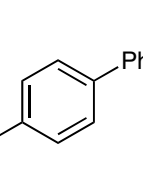 \\
\hline Entry & Ligand & $\mathrm{mol} \%^{\mathrm{a}}$ & Time (h) & Yield $(\%)^{\mathrm{b}}$ \\
\hline $1^{c}$ & - & - & 24 & 52 \\
\hline 2 & dppf & 10 & 14 & 64 \\
\hline 3 & dppe & 10 & 24 & 50 \\
\hline 4 & dppp & 10 & 24 & 39 \\
\hline 5 & $\mathrm{dppb}$ & 10 & 24 & 46 \\
\hline 6 & $\mathrm{PPh}_{3}$ & 20 & 20 & 63 \\
\hline 7 & $\left(4-\mathrm{ClC}_{6} \mathrm{H}_{4}\right)_{3} \mathrm{P}$ & 20 & 6 & 69 \\
\hline 8 & $\left(4-\mathrm{FC}_{6} \mathrm{H}_{4}\right)_{3} \mathrm{P}$ & 20 & 6 & 83 \\
\hline 9 & $\left(\mathrm{C}_{6} \mathrm{~F}_{5}\right)_{3} \mathrm{P}$ & 20 & 6 & 56 \\
\hline 10 & $\left(2-\mathrm{MeC}_{6} \mathrm{H}_{4}\right)_{3} \mathrm{P}$ & 20 & 24 & 53 \\
\hline 11 & $\left(3-\mathrm{MeC}_{6} \mathrm{H}_{4}\right)_{3} \mathrm{P}$ & 20 & 20 & 62 \\
\hline 12 & $\left(4-\mathrm{MeC}_{6} \mathrm{H}_{4}\right)_{3} \mathrm{P}$ & 20 & 20 & 66 \\
\hline 13 & $\left(4-\mathrm{MeOC}_{6} \mathrm{H}_{4}\right)_{3} \mathrm{P}$ & 20 & 24 & 50 \\
\hline 14 & {$\left[2,6-(\mathrm{MeO})_{2} \mathrm{C}_{6} \mathrm{H}_{3}\right]_{3} \mathrm{P}$} & 20 & 20 & 39 \\
\hline 15 & $\mathrm{Cy}_{3} \mathrm{P}$ & 20 & 12 & 58 \\
\hline 16 & JohnPhos & 20 & 24 & 45 \\
\hline
\end{tabular}

${ }^{a}$ The total amount of phosphine atoms in each entry are equal.

${ }^{b}$ Determined by ${ }^{1} \mathrm{H}$ NMR spectroscopy with 1,4-dioxane as the internal standard.

${ }^{c} \mathrm{PhSi}(\mathrm{OEt})_{3}$ (2 equiv) were used.

When dried tetra- $n$-butylammonium fluoride ${ }^{13}$ was used for the cross-coupling reactions, the efficiency decreased significantly in comparison to those using tetra- $n$-butylammonium fluoride trihydrate (Table 3, entries 1 vs. 2 and 6 vs. 7), suggesting that the presence of water promotes the coupling. The yield was improved significantly by adding a small amount of water ( $4.8 \mathrm{v} / \mathrm{v} \%$ aqueous toluene) (Table 3, entries 3 and 8). Increasing the amount of added water $(9.1,17$ or $31 \mathrm{v} / \mathrm{v} \%)$ did not improve the results further (Table 3 , entries 4, 5, 9 and 10). These results indicate that addition of a small amount of water accelerates the present cross-coupling reaction. Therefore, tris(4fluorophenyl)phosphine and $4.8 \mathrm{v} / \mathrm{v} \%$ aqueous toluene were chosen as the optimum ligand and solvent, respectively. ${ }^{14-17}$ 
Table 3 Effect of Water on the $10 \%$ Pd/C-Catalyzed Cross-Coupling between 1-Iodo-4-nitrobenzene and Triethoxy(phenyl)silane

\begin{tabular}{|c|c|c|c|c|}
\hline \multirow[b]{2}{*}{ Entry } & \multirow[b]{2}{*}{ Ligand } & \multicolumn{2}{|c|}{$\begin{array}{l}10 \% \mathrm{Pd} / \mathrm{C}(5 \mathrm{~mol} \%) \\
\text { ligand }(20 \mathrm{~mol} \%) \\
\mathrm{TBAF} \cdot 3 \mathrm{H}_{2} \mathrm{O}(2 \text { equiv) }\end{array}$} & $\overbrace{}^{P h}$ \\
\hline & & $\mathrm{H}_{2} \mathrm{O}(\mathrm{v} / \mathrm{v} \%)^{\mathrm{a}}$ & Time (h) & Yield $(\%)^{b}$ \\
\hline $1^{c}$ & $\left(4-\mathrm{ClC}_{6} \mathrm{H}_{4}\right)_{3} \mathrm{P}$ & - & 24 & 64 \\
\hline 2 & $\left(4-\mathrm{ClC}_{6} \mathrm{H}_{4}\right)_{3} \mathrm{P}$ & - & 6 & 69 \\
\hline 3 & $\left(4-\mathrm{ClC}_{6} \mathrm{H}_{4}\right)_{3} \mathrm{P}$ & 4.8 & 6 & 80 \\
\hline 4 & $\left(4-\mathrm{ClC}_{6} \mathrm{H}_{4}\right)_{3} \mathrm{P}$ & 9.1 & 13 & 80 \\
\hline 5 & $\left(4-\mathrm{ClC}_{6} \mathrm{H}_{4}\right)_{3} \mathrm{P}$ & 33 & 24 & 24 \\
\hline $6^{c}$ & $\left(4-\mathrm{FC}_{6} \mathrm{H}_{4}\right)_{3} \mathrm{P}$ & - & 17 & 70 \\
\hline 7 & $\left(4-\mathrm{FC}_{6} \mathrm{H}_{4}\right)_{3} \mathrm{P}$ & - & 6 & 83 \\
\hline 8 & $\left(4-\mathrm{FC}_{6} \mathrm{H}_{4}\right)_{3} \mathrm{P}$ & 4.8 & 4 & 83 \\
\hline 9 & $\left(4-\mathrm{FC}_{6} \mathrm{H}_{4}\right)_{3} \mathrm{P}$ & 9.1 & 4 & 80 \\
\hline 10 & $\left(4-\mathrm{FC}_{6} \mathrm{H}_{4}\right)_{3} \mathrm{P}$ & 17 & 24 & 64 \\
\hline
\end{tabular}

${ }^{\mathrm{a}}$ The percentage indicates the ratio of the volume of water to the mixed solvent volume.

${ }^{\mathrm{b}}$ Determined by ${ }^{1} \mathrm{H}$ NMR spectroscopy with 1,4-dioxane as the internal standard.

${ }^{\text {c }}$ TBAF $3 \mathrm{H}_{2} \mathrm{O}$ was dried at $90{ }^{\circ} \mathrm{C}$ under reduced pressure for $30 \mathrm{~min}$ utes prior to use. ${ }^{13}$

Next, the amount of the ligand $\left[\left(4-\mathrm{F}-\mathrm{C}_{6} \mathrm{H}_{4}\right)_{3} \mathrm{P}\right]$ required for a successful cross-coupling was investigated at $120^{\circ} \mathrm{C}$ using $10 \%$ palladium on carbon ( $5 \mathrm{~mol} \%$ ) as the catalyst. It was found that $10 \mathrm{~mol} \%$ of the ligand (2 equiv with respect to the amount of $10 \% \mathrm{Pd} / \mathrm{C}$ ) was sufficient to catalyze the cross-coupling without any significant suppression of the reaction efficiency (Table 4, entries 14). Furthermore, the amount of $10 \%$ palladium on carbon could be decreased (from $5 \mathrm{~mol} \%$ to $0.5 \mathrm{~mol} \%$ ) in the presence of tris(4-fluorophenyl)phosphine $(1 \mathrm{~mol} \%)$ to give the corresponding biphenyl in $90 \%$ yield (Table 4 , entry 5); a further decrease in the amount of catalyst (to $0.3 \%$ ) reduced the rate of the reaction (Table 4 , entry 6 ). The reaction efficiency decreased at temperatures lower than $120^{\circ} \mathrm{C}$ (Table 4, entries 7 and 8) and was almost the same at $140{ }^{\circ} \mathrm{C}$ (Table 4, entry 9). Hence, subsequent investigations on the substrate scope of the Hiyama crosscoupling were carried out using the combination of $10 \%$ palladium on carbon (5 mol\%) and tris(4-fluorophenyl)phosphine $(1 \mathrm{~mol} \%)$ at $120^{\circ} \mathrm{C}$ (Table 5).

It was found that trimethoxy(phenyl)silanes also reacted with aryl halides to afford the corresponding biphenyls in good yields (Table 5, entries 2 and 9). Both iodobenzene and bromobenzene derivatives, bearing either an electronwithdrawing or electron-donating group on the aromatic ring, readily underwent cross-coupling with trialkoxy(aryl)silanes regardless of the nature of their substituents and
Table 4 Optimization of the Amount of Catalyst and Ligand

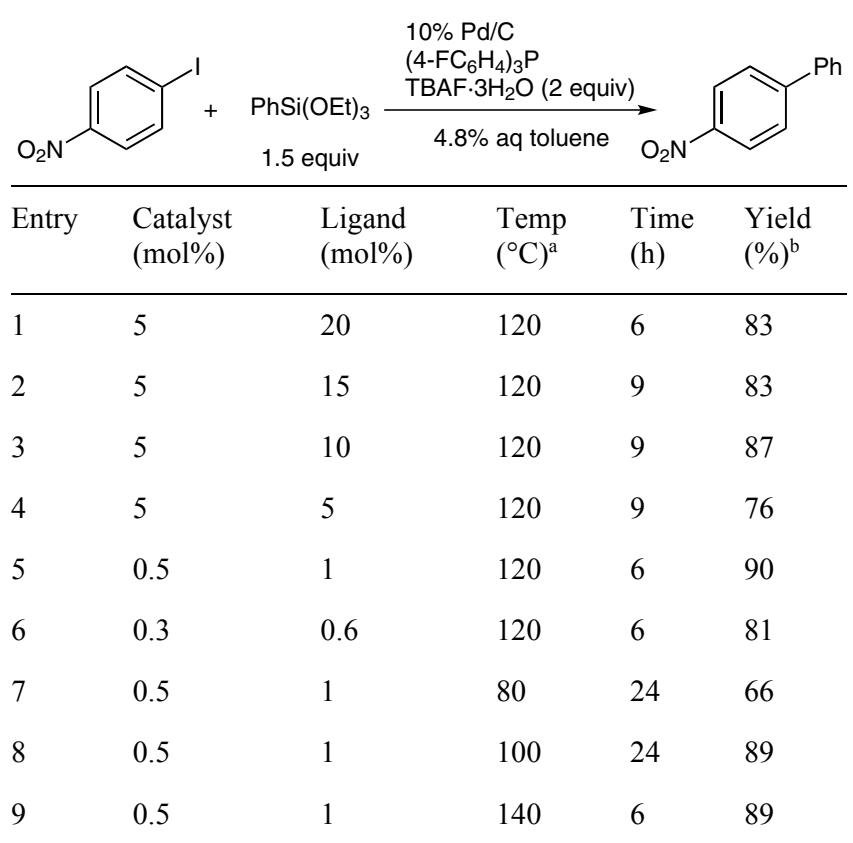

${ }^{a}$ Bath temperature.

${ }^{\mathrm{b}}$ Determined by ${ }^{1} \mathrm{H}$ NMR spectroscopy with 1,4-dioxane as the internal standard.

substitution patterns (Table 5, entries 1-17). However, 1bromonaphthalene was converted into the corresponding biaryl in a low $31 \%$ yield (Table 5, entry 18 ). Heteroarylphenyl moieties are found as important subunits in a variety of functional materials, such as pharmaceuticals, agrochemicals, liquid crystals and natural products. Although heteroatoms sometimes cause a reduction in catalytic activity, as catalyst poisons due to strong coordination with the transition metal center of the catalyst, ${ }^{18}$ the phenylation of both 3-iodopyridine and 3-bromopyridine proceeded smoothly under the present conditions to give the desired phenylpyridines in very high yields (Table 5, entries 19 and 20). Furthermore, the desired phenylated product was even obtained from the reaction of 1-chloro4-nitrobenzene, in a moderate yield, despite the low reactivity of chloroarenes based on their difficult oxidative addition to the metal in palladium-catalyzed crosscouplings.

We previously found that, during the course of a study on the palladium on carbon catalyzed aromatic amination of aryl halides, ${ }^{9 \mathrm{~h}}$ a very small amount of palladium leached from the catalyst into the reaction medium when using $1,1^{\prime}$-bis(diphenylphosphino)ferrocene as the phosphine ligand, which proved to be a very active catalyst species. Since tris(4-fluorophenyl)phosphine was used as the phosphine ligand in the present reaction, the extent of palladium leaching was also examined. Following the crosscoupling reaction of 1-iodo-4-nitrobenzene with triethoxy(phenyl)silane (1.5 equiv) under the optimized conditions, the reaction mixture was filtered successively through 0.45 and $0.20 \mu \mathrm{m}$ membrane filters, and the con- 
Table 5 Cross-Coupling of Various Aryl Halides with Triethoxy(aryl)silanes

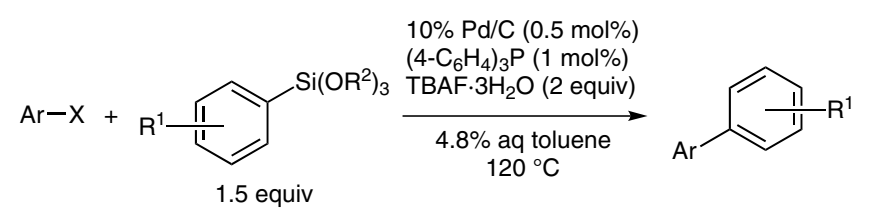

\begin{tabular}{|c|c|c|c|c|c|}
\hline Entry & $\operatorname{Ar}-\mathrm{X}$ & $\mathrm{R}^{1}$ & $\mathrm{R}^{2}$ & $\begin{array}{l}\text { Time } \\
\text { (h) }\end{array}$ & $\begin{array}{l}\text { Yield } \\
(\%)^{\mathrm{a}}\end{array}$ \\
\hline 1 & $4-\mathrm{O}_{2} \mathrm{NC}_{6} \mathrm{H}_{4} \mathrm{I}$ & $\mathrm{H}$ & Et & 6 & 88 \\
\hline 2 & $4-\mathrm{O}_{2} \mathrm{NC}_{6} \mathrm{H}_{4} \mathrm{I}$ & $\mathrm{H}$ & $\mathrm{Me}$ & 6 & 83 \\
\hline 3 & $4-\mathrm{O}_{2} \mathrm{NC}_{6} \mathrm{H}_{4} \mathrm{I}$ & $4-\mathrm{Cl}$ & Et & 6 & 75 \\
\hline 4 & $4-\mathrm{O}_{2} \mathrm{NC}_{6} \mathrm{H}_{4} \mathrm{I}$ & $4-\mathrm{Me}$ & Et & 12 & 80 \\
\hline 5 & $4-\mathrm{MeOC}_{6} \mathrm{H}_{4} \mathrm{I}$ & $\mathrm{H}$ & Et & 6 & 85 \\
\hline 6 & $4-\mathrm{MeOC}_{6} \mathrm{H}_{4} \mathrm{I}$ & $4-\mathrm{Cl}$ & Et & 9 & 83 \\
\hline 7 & $4-\mathrm{MeOC}_{6} \mathrm{H}_{4} \mathrm{I}$ & 4-Me & Et & 12 & 79 \\
\hline 8 & $4-\mathrm{O}_{2} \mathrm{NC}_{6} \mathrm{H}_{4} \mathrm{Br}$ & $\mathrm{H}$ & Et & 6 & 81 \\
\hline 9 & $4-\mathrm{O}_{2} \mathrm{NC}_{6} \mathrm{H}_{4} \mathrm{Br}$ & $\mathrm{H}$ & $\mathrm{Me}$ & 4.5 & 80 \\
\hline 10 & $4-\mathrm{NCC}_{6} \mathrm{H}_{4} \mathrm{Br}$ & $\mathrm{H}$ & Et & 12 & 85 \\
\hline 11 & $4-\mathrm{OHCC}_{6} \mathrm{H}_{4} \mathrm{Br}$ & $\mathrm{H}$ & Et & 12 & 86 \\
\hline 12 & 4- $\mathrm{AcC}_{6} \mathrm{H}_{4} \mathrm{Br}$ & $\mathrm{H}$ & Et & 12 & 86 \\
\hline 13 & $3-\mathrm{AcC}_{6} \mathrm{H}_{4} \mathrm{Br}$ & $\mathrm{H}$ & Et & 24 & $49^{\mathrm{b}}$ \\
\hline 14 & 4- $\mathrm{MeOC}_{6} \mathrm{H}_{4} \mathrm{Br}$ & $\mathrm{H}$ & Et & 24 & 83 \\
\hline 15 & $3-\mathrm{MeOC}_{6} \mathrm{H}_{4} \mathrm{Br}$ & $\mathrm{H}$ & Et & 12 & 90 \\
\hline 16 & $2-\mathrm{MeOC}_{6} \mathrm{H}_{4} \mathrm{Br}$ & $\mathrm{H}$ & Et & 17 & 80 \\
\hline 17 & $4-\mathrm{MeOC}_{6} \mathrm{H}_{4} \mathrm{Br}$ & 4-Me & Et & 24 & 77 \\
\hline 18 & 1-bromonaphthalene & $\mathrm{H}$ & Et & 24 & $31^{\mathrm{b}}$ \\
\hline 19 & 3-iodopyridine & $\mathrm{H}$ & Et & 12 & 85 \\
\hline 20 & 3-bromopyridine & $\mathrm{H}$ & Et & 18 & 81 \\
\hline 21 & $4-\mathrm{O}_{2} \mathrm{NC}_{6} \mathrm{H}_{4} \mathrm{Cl}$ & $\mathrm{H}$ & Et & 18 & 47 \\
\hline
\end{tabular}

${ }^{a}$ Yield of isolated product.

${ }^{b}$ Determined by ${ }^{1} \mathrm{H}$ NMR spectroscopy with 1,4-dioxane as the internal standard.

centration of leached palladium species in the filtrate was measured by inductively coupled plasma atomic emission spectroscopy (ICP-AES). Although $3.8 \%$ of the used amount of palladium $(0.5 \mathrm{~mol} \%)$ was detected in the filtrate, no palladium species was present in the coupled product after purification by silica gel column chromatography, suggesting that the leached palladium species was removed readily to a less than detectable level $(<1 \mathrm{ppm})$.

In conclusion, we have demonstrated an efficient and practical protocol for the synthesis of biaryls via the palladium on carbon catalyzed heterogeneous Hiyama crosscoupling in the presence of a small amount of water as a promoter. While a small amount of palladium metal leaching from the catalyst into the reaction mixture was observed, the leached palladium species could be removed completely by silica gel column chromatography to afford the uncontaminated cross-coupled product. It is worth noting that only $0.5 \mathrm{~mol} \%$ of the palladium catalyst was required to promote the cross-coupling effectively. The results of the present investigation complements our previous report on the ligand-free palladium on carbon $(0.5 \mathrm{~mol} \%)$ catalyzed Hiyama cross-coupling reaction in the presence of acetic acid ( 1.5 equiv) and tetra- $n$-butylammonium fluoride trihydrate ( 2 equiv) in toluene. ${ }^{12}$

$10 \% \mathrm{Pd} / \mathrm{C}$ (K-type, NX-type; dry) was supplied by the N.E. Chemcat Corporation (Tokyo, Japan). All reagents and solvents were purchased from commercial sources and were used without further purification. Flash column chromatography was performed using silica gel $60 \mathrm{~N}$ (Kanto Chemical Co., Inc., 63-210 $\mu \mathrm{m}$ spherical, neutral).

Hiyama Cross-Coupling; General Procedure

A mixture of TBAF $3 \mathrm{H}_{2} \mathrm{O}(631 \mathrm{mg}, 2.00 \mathrm{mmol}), 10 \% \mathrm{Pd} / \mathrm{C}(5.4$ $\mathrm{mg}, \quad 5.00 \mu \mathrm{mol})$, tris(4-fluorophenyl)phosphine $(3.2 \mathrm{mg}, 10.0$ $\mu \mathrm{mol})$, aryl halide $(1.00 \mathrm{mmol})$, and triethoxy(aryl)silane $(1.50$ $\mathrm{mmol})$ in toluene- $\mathrm{H}_{2} \mathrm{O}(2 \mathrm{~mL} / 100 \mu \mathrm{L})$ was stirred at $120^{\circ} \mathrm{C}$ under an $\mathrm{Ar}$ atmosphere (balloon) until the aryl halide was completely consumed [monitored by GC-MS (JMS-Q1000GC Mk 2 from JEOL, Tokyo) and TLC], and then passed through a Celite pad to remove the catalyst. To the filtrate were added EtOAc $(50 \mathrm{~mL})$ and sat. aq $\mathrm{NH}_{4} \mathrm{Cl}$ soln $(50 \mathrm{~mL})$, and the layers were separated. The aq layer was extracted with EtOAc $(10 \mathrm{~mL})$ and the combined organic layers dried over $\mathrm{MgSO}_{4}$, filtered, and concentrated in vacuo. The residue was purified by flash column chromatography on silica gel (hexane-EtOAc) to give the analytically pure biphenyl. The structure of the product was confirmed by comparison of NMR spectroscopic data with those reported in the literature (see the Supporting Information).

\section{Acknowledgment}

We sincerely thank N.E. Chemcat Corporation for the gift of the catalysts.

Supporting Information for this article is available online at http://www.thieme-connect.com/ejournals/toc/synthesis.

\section{References}

(1) For reviews on the Hiyama cross-coupling, see: (a) Hiyama, T.; Shirakawa, E. In Handbook of Organopalladium Chemistry for Organic Synthesis; Vol. 1; Negishi, E.; de Meijere, A., Eds.; Wiley-Interscience: New York, 2002, 285. (b) Denmark, S. E.; Sweis, R. F. Acc. Chem. Res. 2002, 35, 835. (c) Denmark, S. E.; Ober, M. H. Aldrichimica Acta 2003, 36, 76. (d) Denmark, S. E.; Regens, C. S. Acc. Chem. Res. 2008, 41, 1486. (e) Denmark, S. E.; Liu, J. H.-C. Angew. Chem. Int. Ed. 2010, 49, 2.

(2) For related papers before 2006, see reference 1. (a) Shi, S.; Zhang, Y. J. Org. Chem. 2007, 72, 5927. (b) Pan, C.; Liu, M.; Zhao, L.; Wu, H.; Ding, J.; Cheng, J. Catal. Commun. 2008, 9, 1685. (c) Zhang, L.; Wu, J. J. Am. Chem. Soc. 2008, 130, 12250. (d) Zhang, L.; Qing, J.; Yang, P.; Wu, J. Org. Lett. 2008, 10, 4971. (e) Alacid, E.; Najera, C.J. Org. Chem. 2008, 73, 2315. (f) Chen, S. N.; Wu, W. Y.; Tsai, F. Y. 
Tetrahedron 2008, 64, 8164. (g) So, C. M.; Lee, H. W.; Lau, C. P.; Kwong, F. Y. Org. Lett. 2009, 11, 317. (h) Denmark, S. E.; Smith, R. C.; Chang, W. T. T.; Muhuhi, J. M. J. Am. Chem. Soc. 2009, 131, 3104. (i) Denmark, S. E.; Werner, N. S. J. Am. Chem. Soc. 2010, 132, 3612. (j) Beaulieu, L.-P. B.; Delvos, L. B.; Charette, A. B. Org. Lett. 2010, 12, 1348.

(k) Nakao, Y.; Takeda, M.; Matsumoto, T.; Hiyama, T. Angew. Chem. Int. Ed. 2010, 49, 4447. (1) Molander, G. A.; Iannazzo, L. J. Org. Chem. 2011, 76, 9182. (m) Cheng, K.; Wang, C.; Ding, Y.; Song, Q.; Qi, C.; Zhang, X.-M. J. Org. Chem. 2011, 76, 9261.

(3) For reviews, see: (a) Yin, L.; Liebscher, J. Chem. Rev. 2007, 107, 133. (b) Climent, M. J.; Corma, A.; Iborra, S. Chem. Rev. 2011, 111, 1072.

(4) (a) Pachon, L. D.; Thathagar, M. B.; Hartl, F.; Rothenberg, G. Phys. Chem. Chem. Phys. 2006, 8, 151. (b) Ranu, B. C.; Dey, R.; Chattopadhyay, K. Tetrahedron Lett. 2008, 49 , 3430. (c) Dey, R.; Chattopadhyay, K.; Ranu, B. C. J. Org. Chem. 2008, 73, 9461.

(5) Srimani, D.; Sawoo, S.; Sarkar, A. Org. Lett. 2007, 9, 3639.

(6) Borkowski, T.; Subik, P.; Trzeciak, A. M.; Wolowiec, S. Molecules 2011, 16, 427.

(7) Nishimura, S. Handbook of Heterogeneous Catalytic Hydrogenation for Organic Synthesis; Wiley-Interscience: New York, 2001

(8) For reviews on palladium on carbon catalyzed crosscoupling reactions, see: (a) Nishida, M.; Tagata, T. J. Synth. Org. Chem. Jpn. 2004, 62, 737. (b) Seki, M. J. Synth. Org. Chem. Jpn. 2006, 64, 853. (c) Seki, M. Synthesis 2006, 2975. (d) Felpin, F.-X.; Ayad, T.; Mitra, S. Eur. J. Org. Chem. 2006, 2679. (e) Phan, N. T. S.; Sluys, M. V. D.; Jones, C. W. Adv. Synth. Catal. 2006, 348, 609. (f) Felpin, F.-X.; Fouquet, E. ChemSusChem 2008, 1, 718. (g) Pal, M. Synlett 2009, 2896. (h) Lamblin, M.; Nassar-Hardy, L.; Hierso, J.C.; Fouquet, E.; Felpin, F.-X. Adv. Synth. Catal. 2010, 352, 33. (i) Molnár, A. Chem. Rev. 2011, 111, 2251.

(j) Djakovitch, L.; Batail, N.; Genelot, M. Molecules 2011, 16, 5241. (k) Djakovitch, L.; Koehler, K.; de Vries, J. G. In Nanoparticles and Catalysis; Astruc, D., Ed.; Wiley-VCH: Weinheim, 2001, 303.

(9) (a) Sajiki, H.; Kurita, T.; Kozaki, A.; Zhang, G.; Kitamura, Y.; Maegawa, T.; Hirota, K. J. Chem. Res. 2004, 593; erratum in J. Chem. Res. 2005, 344. (b) Sajiki, H.; Kurita, T.; Kozaki, A.; Zhang, G.; Kitamura, Y.; Maegawa, T.; Hirota, K. Synthesis 2005, 537; erratum in Synthesis 2005, 852.

(c) Sajiki, H.; Zhang, G.; Kitamura, Y.; Maegawa, T.; Hirota, K. Synlett 2005, 619, erratum in Synlett 2005, 1046. (d) Maegawa, T.; Kitamura, Y.; Sako, S.; Udzu, T.; Sakurai, A.; Tanaka, A.; Kobayashi, Y.; Endo, K.; Bora, U.; Kurita, T.; Kozaki, A.; Monguchi, Y.; Sajiki, H. Chem.-Eur. J. 2007, 13, 5937. (e) Kitamura, Y.; Sakurai, A.; Udzu, T.; Maegawa, T.; Monguchi, Y.; Sajiki, H. Tetrahedron 2007, 63, 10596. (f) Kitamura, Y.; Sako, S.; Udzu, T.; Tsutui, A.; Maegawa, T.; Monguchi, Y.; Sajiki, H. Chem. Commun. 2007, 5069. (g) Mori, S.; Yanase, T.; Aoyagi, S.; Monguchi, Y.; Maegawa, T.; Sajiki, H. Chem.-Eur. J. 2008, 14, 6994. (h) Monguchi, Y.; Kitamoto, K.; Ikawa, T.; Maegawa, T.; Sajiki, H. Adv. Synth. Catal. 2008, 350, 2767. (i) Kitamura, Y.; Sako, S.; Tsutsui, A.; Monguchi, Y.; Maegawa, T.; Kitade, Y.; Sajiki, H. Adv. Synth. Catal. 2010, 352, 718. (j) Yabe, Y.; Maegawa, T.; Monguchi, Y.; Sajiki, H. Tetrahedron 2010, 66, 8654. (k) Monguchi, Y.; Hattori, T.;
Miyamoto, Y.; Yanase, T.; Sawama, Y.; Sajiki, H. Adv. Synth. Catal. 2012, 354, 2561.

(10) Komáromi, A.; Szabó, F.; Novák, Z. Tetrahedron Lett. 2010 , $51,54$.

(11) Yanase, T.; Mori, S.; Monguchi, Y.; Sajiki, H. Chem. Lett 2011, 40, 910.

(12) Yanase, T.; Monguchi, Y.; Sajiki, H. RSC Adv. 2012, 2, 590

(13) For the procedure for the preparation of dried TBAF, see: (a) Kim, D. W.; Jeong, H.-J.; Lim, S. T.; Sohn, M.-H. Angew. Chem. Int. Ed. 2008, 47, 8404. (b) Sharma, R. K.; Fly, J. L. J. Org. Chem. 1983, 48, 2112. (c) Cox, D. P.; Terpinski, J.; Lawrynowicz, W. J. Org. Chem. 1984, 49 , 3216.

(14) The palladium particle size and carbon surface area of the $10 \% \mathrm{Pd} / \mathrm{C}$ (K-type, N.E. Chemcat Corporation) used in this study are approximately $5 \mathrm{~nm}$ and $1100 \mathrm{~m}^{2} / \mathrm{g}$, respectively.

(15) The protocol and outcome of the cross-coupling between 1iodo-4-nitrobenzene and triethoxy(phenyl)silane was not affected when $10 \% \mathrm{Pd} / \mathrm{C}$ obtained from different suppliers was used (see Table 6).

Table 6

\begin{tabular}{lll}
\hline Supplier & Time (h) & Yield (\%) $^{\mathrm{a}}$ \\
\hline Aldrich & 6 & 87 \\
Acros & 6 & 83 \\
Wako & 6 & 89 \\
N.E. Chemcat, NX-type & 4 & 87 \\
N.E. Chemcat, K-type & 6 & 90
\end{tabular}

${ }^{a}$ Determined by ${ }^{1} \mathrm{H}$ NMR spectroscopy with 1,4-dioxane as the internal standard.

(16) When $\mathrm{Pd}(\mathrm{OAc})_{2}(5 \mathrm{~mol} \%)$, as a homogeneous catalyst, and $\left(4-\mathrm{FC}_{6} \mathrm{H}_{4}\right)_{3} \mathrm{P}(20 \mathrm{~mol} \%)$ were used for the cross-coupling of 1-iodo-4-nitrobenzene with triethoxy(phenyl)silane (1.5 equiv) in $4.8 \%$ aqueous toluene at $120^{\circ} \mathrm{C}$ (bath temperature), the desired 4-nitrobiphenyl was obtained in $72 \%$ yield, together with the homo-coupled product derived from the iodide, 4,4'-dinitrobiphenyl, in 5\% yield. The use of $10 \%$ $\mathrm{Pd} / \mathrm{C}$ was more appropriate for the present conditions compared to those applied in Table 3, entry 7; see also the supporting information in our previous communication. ${ }^{11}$

(17) In the presence of a small amount of water, the alkoxy groups of the triethoxy(aryl)silane would be hydrated into the corresponding hydroxy groups, and the electrophilicity of the silicon atom would increase. On the other hand, addition of an excess amount of water resulted in the formation of inactive caged siloxane derivatives, see reference 11 and: (a) Hasegawa, I.; Ino, K.; Ohnishi, H. Appl. Organomet. Chem. 2003, 17, 287. (b) Iwamura, T.; Adachi, K.; Chujo, Y. Chem. Lett. 2010, 39, 354.

(18) (a) Feuerstein, M.; Doucet, H.; Santelli, M. J. Organomet. Chem. 2003, 687, 327. (b) Navarro, O.; Marion, N.; Mei, J.; Nolan, S. P. Chem.-Eur. J. 2006, 12, 5142. (c) Shi, S.; Zhang, Y. Green Chem. 2008, 10, 868. 